Proceedings

\title{
Behavior of Natural Organic Polymer-Based Plaster Mortars under the Influence of Water ${ }^{+}$
}

\author{
Alexandra Olga Pintea ${ }^{1, *}$, Marta Ioana Moldoveanu ${ }^{1}$ and Daniela Lucia Manea ${ }^{2}$ \\ 1 Faculty of Civil Engineering, Technical University of Cluj-Napoca, C. Daicoviciu Street 15, \\ 400020 Cluj-Napoca, Romania; Marta.Moldoveanu@ccm.utcluj.ro \\ 2 Faculty of Civil Engineering, Technical University of Cluj-Napoca, Memorandumului Street 28, \\ 400411 Cluj-Napoca, Romania; Daniela.Manea@ccm.utcluj.ro \\ * Correspondence: alexandra_pintea91@yahoo.com \\ + Presented at the 14th International Conference on Interdisciplinarity in Engineering-INTER-ENG 2020, \\ Târgu Mureș, Romania, 8-9 October 2020.
}

Published: 3 February 2021

check for updates

\begin{abstract}
The influence of polymers upon building materials has been present since ancient times, but it was neglected for a long period. The present research discusses the effect of natural organic polymers (casein, rice, egg) in the formula of classical plastering according to the experimental research aiming at finding out the water absorption coefficient and the softening coefficient. The main objective of this work lies in identifying the most performance-related natural polymer which can determine the most efficient impermeability that can lead to the best values for the plaster mortar formula.
\end{abstract}

Keywords: plaster mortar; water absorption; casein; rice; egg

\section{Introduction}

Our research has identified a large variety of additives to be found in historical buildings, such as casein, beer, and master oils. Various additives have been applied to historical buildings, including polysaccharides, used either as powder or glue, proteins originating in animal glues, and casein. The research established that the use of such additives leads to the improvement of mechanical properties and the increase of resistance to water [1].

Due to the capillary rise of water in the ground or from infiltration, there comes out the issue of humidity in masonry leading to wall damaging and worse building materials properties. The phenomenon manifests in the poor adherence of paint, and in worse cases in plaster detaching. Humidity rise remains a constant issue in time which has a high impact on the costs for all of the building's life.

According to the findings of Dorin-Victor POPA in the book "Contributions to the theory and practice of historical and social cultural buildings foundations and walls drainage" [2], there is a direct infiltration when the foundation masonry is in direct contact with the underground water when the material of the masonry is saturated with water which rises through capillarity phenomena in the masonry weight.

When the surfaces of the foundations are not in direct contact with the underground water, it however reaches the surfaces due to the capillary forces in the pores (the smaller the soil grains and pores, the stronger such forces). In general, the liquid does not maintain the same level, but it rises more with a smaller column section. This is the reason for which the water rise level is inversely proportional to the pore diameter [3].

When the masonry is made with rocks that do not have the capacity of capillary absorption, the humidity capillary rise will be diminished and the means of getting to the member surface lies only 
in the mortar layers. This is the reason for which the Romans used, in masonry elevations, porous materials such as volcanic rock which has a high water absorption capacity and also a good thermal insulation property, while for the foundations, they used solid and compact materials such as granite. The thicker the masonry member, the higher the vertically transmitted humidity [4].

The research established that the use of natural polymers as additives in the plaster mortar improves the mechanical properties and the property of resistance to water, as well as the differing speeds of carbonation and textures. The natural polymers, in compatible traditional building materials, are utilized in the restoration of the architectural heritage and modern architecture [5-8]. Starch alters the air content, the density, the water retaining capacity, the setting time, and other properties. The cactus extract increases plasticity, water absorption, and stabilizes resistance to salt. Using jaggery in concrete mixtures improves workability and reduces segregation. Animal glue in mortars improves mechanical strength. Olive oil ameliorates mortar imperviousness. Jelly rice paste, the gluey liquid made from elm wood chips, other additions, the dark brown glue from the sugar stems and leaves, oils, egg whites, liquid resins, cactus sticky liquid, latex from natural rubber are proteins and natural polymers identified in mortars [9-13].

The softening coefficient is defined as the ratio between the resistance to compression of the water-saturated material and of the dry material. It is the property of the materials of not destroying or essentially modifying properties under long-term water saturation influence.

\section{Materials and Methods}

\subsection{Materials}

Our formulae contained grade CEM I $42.5 \mathrm{R}$ cement, which is a pure cement used for not affecting the properties at all and surveying only the influence of the polymer amount in the mixture. The aggregates used in the formulae were taken from a gravel pit from the Someș riverbank and were of size $0-4 \mathrm{~mm}$. The water used in the tests was taken from the local water distribution network in Cluj-Napoca. The polymers under question were casein, rice, and egg. Casein is a protein extracted from milk, dried, and then milled. The rice grains were ground, for one formula being boiled and the water strained after boiling was used. The egg used was uncooked and fresh [1]. For more details regarding the materials used in the formulae, see the article "Influence of Natural Organic Polymers upon Plaster Mortar Workability" [14].

\subsection{Methods}

The tests were carried out in the Building Materials Laboratory of the Faculty of Civil Engineering in Cluj-Napoca. The research methodology required the elaboration of our own plaster mortar formulae, to which natural polymers were added as additives and the determination of the water absorption content and softening coefficient according to SR EN 1015-18:2004 [15].

\subsubsection{Determination of the Water Absorption Coefficient}

The water absorption coefficient caused by capillary action was measured in prismatic mortar specimens, in well-defined conditions, at atmospheric pressure. After drying up to the constant weight. A face of the specimen was immersed in $5-10 \mathrm{~mm}$ water, for a specified time interval. In this way, the weight increase was determined.

For this determination, one requires a vessel with a minimum height of $20 \mathrm{~mm}$ and a plane surface large enough to contain the immersed specimens. The vessel should be provided with a device to maintain a constant water level. In order to put the specimen at an acceptable distance from the vessel bottom, one needs four supports or similar elements for each specimen that allow only a minimum contact surface with the specimen. For sealing purposes, paraffin or a reactive synthetic resin with a melting point higher than 60 degrees Celsius can be used. 
The preparation and drying of the specimens were done in accordance with SR EN 1015-11 [16]. The sealing material was applied to the four long faces of the specimen and then they were crushed into two pieces. They were dried until getting to a constant weight in a ventilated dry kiln, at a temperature of 60 degrees Celsius \pm 5 degrees Celsius. The constant weight is reached when, after two successive measurements made in an interval of $24 \mathrm{~h}$ during drying, the amount of water loss is smaller than or equal to $0.2 \%$ of the total weight.

The specimens are placed in the vessel with the fractured prism surface towards the bottom of the vessel, fitted onto the four supports so that the vessel bottom is not touched and the depth of immersion is $5-10 \mathrm{~mm}$ during testing. (See Figure 1). Air bubble formation under the specimens should be avoided.

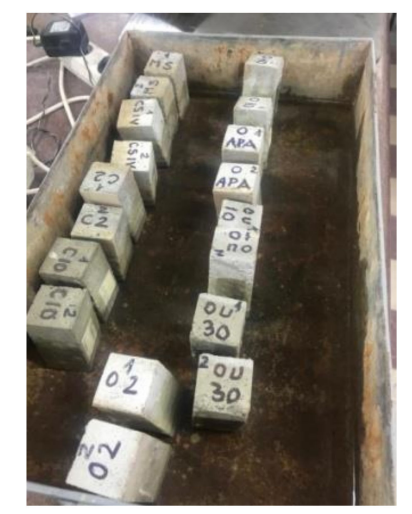

Figure 1. Immersed specimens.

After $10 \mathrm{~min}$, the specimens were taken out of the vessel, quickly dried with a wet cloth, weighted, and replaced in the vessel. The procedure was repeated $90 \mathrm{~min}$ later (Equation (1)). After $24 \mathrm{~h}$, they were weighted again, then specimens were broken along their length so that prisms of the approximate size of $80 \times 40 \times 20 \mathrm{~mm}$ were obtained. The water penetration height at the specimen center was measured parallel to the length of $80 \mathrm{~mm}$, with a deviation of a maximum of $1 \mathrm{~mm}$.

$$
\mathrm{C}=0.1\left(\mathrm{M}_{90}-\mathrm{M}_{10}\right) \mathrm{kg} /\left(\mathrm{m}^{2} \min ^{0.5}\right),
$$

The capillarity caused water absorption coefficient was by definition equal to the straight line slope uniting the significant points of the measurements performed at 10 and $90 \mathrm{~min}$, respectively (Equation (2)). For repair mortars, the water absorption at $24 \mathrm{~h}$ was calculated as follows [15].

$$
\mathrm{C}=0.625\left(\mathrm{M}_{24}-\mathrm{M}_{0}\right) \mathrm{kg} / \mathrm{m}^{2},
$$

\subsubsection{Determination of the Softening Coefficient}

This coefficient reflects the property of the materials of not destroying or essentially modifying their property under the effect of long-term water saturation. This property is estimated through the softening coefficient $(K)$, defined as the ratio between the resistance to compression of the water-saturated material $\left(R_{s}\right)$ and the resistance of the dry material $\left(R_{u}\right)$ (Equation (3)).

$$
K=\frac{R_{s}}{R_{u}},
$$

For the purpose of this determination, it is necessary to use a minimum of three samples. The determination was carried out on the halves of three broken specimens, after performing the flexural tensile stress. Three prism halves were preserved by immersing them in a vessel with water, in accordance with the conditions stipulated in the norm SR EN 1015, and the other three prism halves were immersed in a vessel with water where water passed by $1 \mathrm{~cm}$ the prisms (See Figure 2). 
The samples were left in water until they reached a constant weight. No protecting cover was applied onto the surface of the samples.

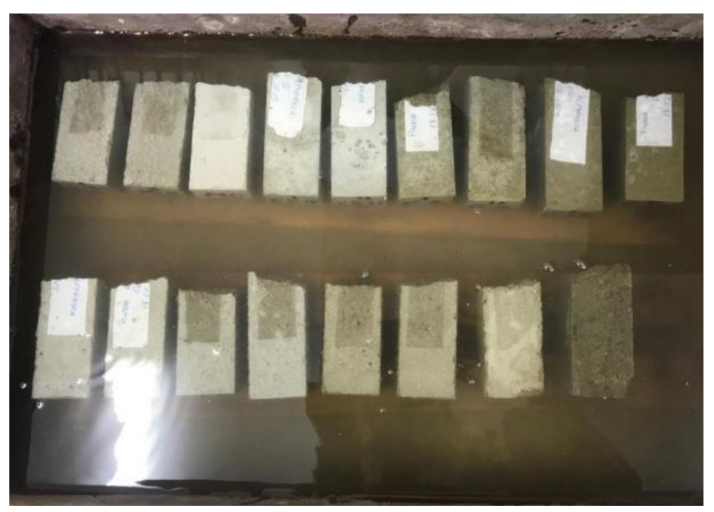

Figure 2. Fully water-soaked specimens.

After these wet samples reached a constant weight, they were tested for compression. The dry samples were also tested for compression on the same day. The ratio between the resistance to compression of the wet samples and the resistance to compression of the dry samples gives the softening coefficient $(K)$.

\section{Results and Discussion}

\subsection{Determination of the Water Absorption Coefficient}

In order to study the water absorption level, six specimens of size $160 \times 40 \times 40 \mathrm{~mm}$ were made for each formula. They were tested to the flexural tensile stress and then the prism halves were tested for water absorption.

Table 1 presents the average values for water absorption $(\mathrm{g})$ in the case of the mortars under investigation for the purpose of the present article.

Table 1. Average values for water absorption.

\begin{tabular}{cccc}
\hline \multirow{2}{*}{ Formula } & \multicolumn{3}{c}{ Evolution in Time of Water Absorption (g) } \\
\cline { 2 - 4 } & at $\mathbf{1 0} \mathbf{~ m i n}$ & at $\mathbf{3 0} \mathbf{~ m i n}$ & at $\mathbf{9 0} \mathbf{~ m i n}$ \\
\hline CS IV & 1.65 & 2.25 & 3.45 \\
MPC 2\% & 1.1 & 1.35 & 1.9 \\
MPC 10\% & 0.5 & 0.5 & 0.65 \\
MPR 2\% & 1.35 & 1.9 & 3.2 \\
MPR 10\% & 1.2 & 1.5 & 2.2 \\
MPRW & 2.4 & 3.25 & 4.7 \\
MPE 10\% & 0.5 & 0.5 & 0.7 \\
MPE 30\% & 0.3 & 0.3 & 0.3 \\
\hline
\end{tabular}

The name of the formulae has the following meaning: CS IV—cement plaster mortar (no additives); MPC 2\%-CS IV mortar with 2\% casein; MPC 10\%-CS IV mortar with 10\% casein; MPR $2 \%$-CS IV mortar with $2 \%$ rice; MPR $10 \%$ - CS IV mortar with 10\% rice; MPRW 2\%—CS IV product with rice water; MPE 10\%-CS IV mortar with 10\% egg white; MPE 30\%-CS IV mortar with 30\% egg white.

Figure 3 shows that the conventional plaster mortar formula (CS IV) absorbs the highest amount of water, immediately after the rice water formula (MPRW). In the rest of the formulae, it is also visible that the polymer has a positive influence in so far as water absorption is concerned. Formula MPC $10 \%$ is thus one of the best formulae for water absorption, placed in the second position together with 
MPE 10\%. The formula MPE 30\% lies in the first place. It is noticed that the polymer has an influence through its low water absorption, which diminishes by adding polymers.

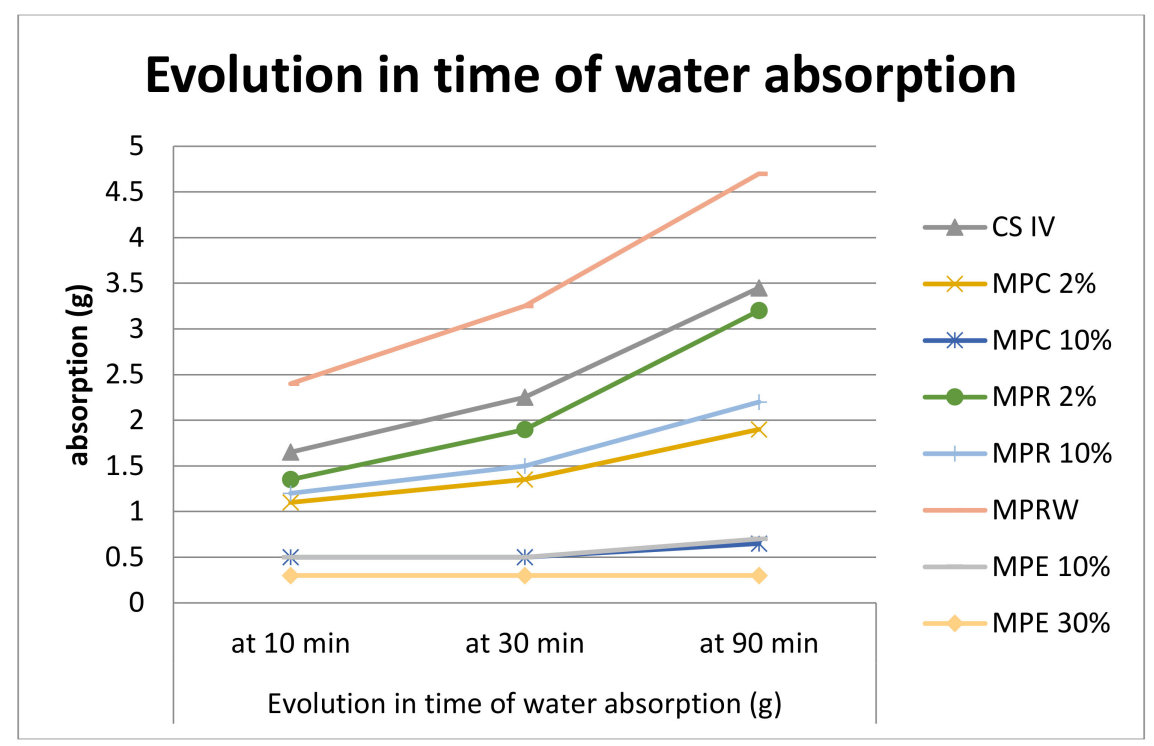

Figure 3. Graphical representation of water absorption at 10, 30, and $90 \mathrm{~min}$ for the mortars included in the experimental program.

Figure 4 presents water absorption at 10, 30, and $90 \mathrm{~min}$ for the formulae MPC $2 \%$, MPC $10 \%$, MPR 2\%, MPR 10\%, MPRW. In Figure 4, one can notice that the rice effect is not so beneficial as casein influence is, for water absorption. The values of the mortars containing rice increase with time, while in the mortars with casein, these values come to a standstill or the rise is very small. All the rice-based mortar formulae present higher values of water absorption than casein-based mortar formulae. Formula MPRW exhibits the highest water absorption level. Probably as the rice water left many capillary pores when evaporating. The higher the rice content in the mortar formulae, the lower water absorption. Mortar formulae with casein exhibit the lowest level of water absorption. At $10 \mathrm{~min}$, formulae MPR 2\%, MPR 10\%, MPC 2\% absorb approximately the same amount of water.

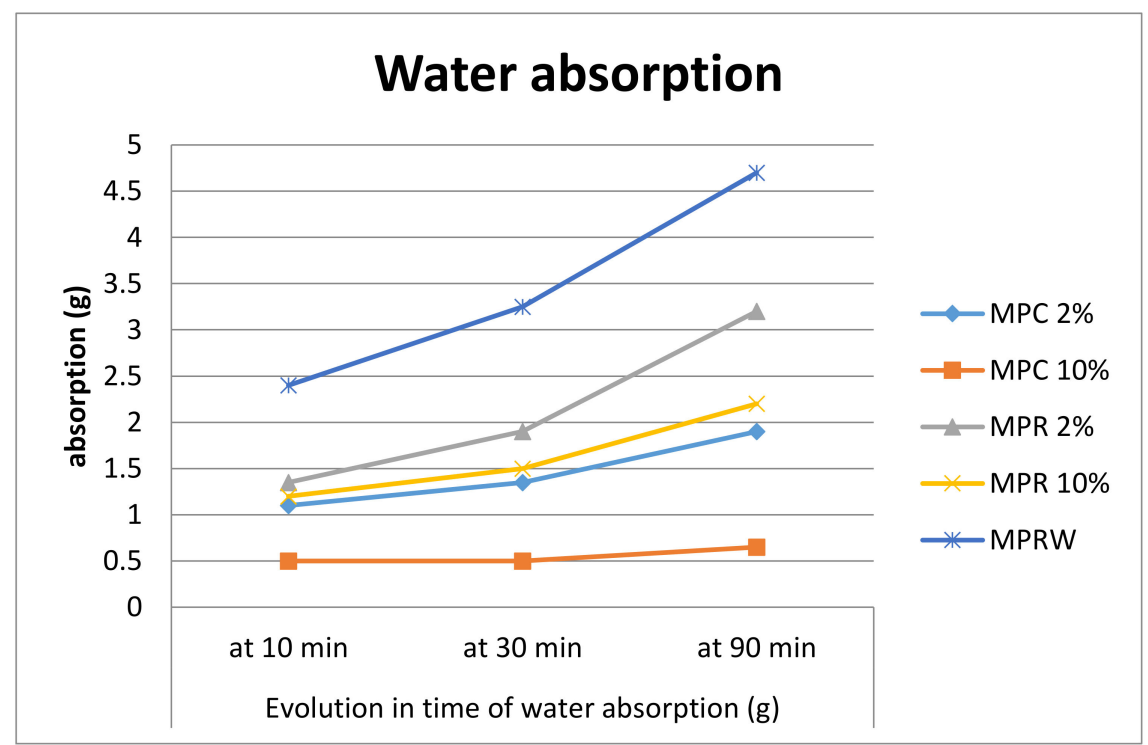

Figure 4. Graphical representation of water absorption at 10, 30, and $90 \mathrm{~min}$ for the mortars MPC 2\%, MPC 10\%, MPR 2\%, MPR 10\%, MPRW. 
Figure 5 presents water absorption at 10, 30 and 90 min for formulae MPR 2\%, MPR 10\%, MPRW, MPE 10\%, MPE 30\%. In Figure 5, one can notice that similar to the previous case, rice-based mortars (MPR 2\%, MPR 10\%, MPRW) have higher values for water absorption as compared to egg white based mortars (MPE 10\%, MPE 30\%). The higher the egg white content in mortars, the smaller the water absorption. The influence of the egg is obvious by comparison with that of the rice. The water absorption values of the rice-containing mortars increase in time, while those containing eggs stagnate or increase very poorly. Mortar MPE $10 \%$ has water absorption during the first 10 minutes, after $30 \mathrm{~min}$ it stops absorbing water and after $90 \mathrm{~min}$ it absorbs water very little. Mortar MPE 30\% absorbs water during the first $10 \mathrm{~min}$ and then it stops absorbing water. In so far as water absorption is concerned, the best formulae is MPE 30\%, followed by both MPE 10\% and MPC 10\%. The presence of the egg white in the mortar composition interrupts capillarity.

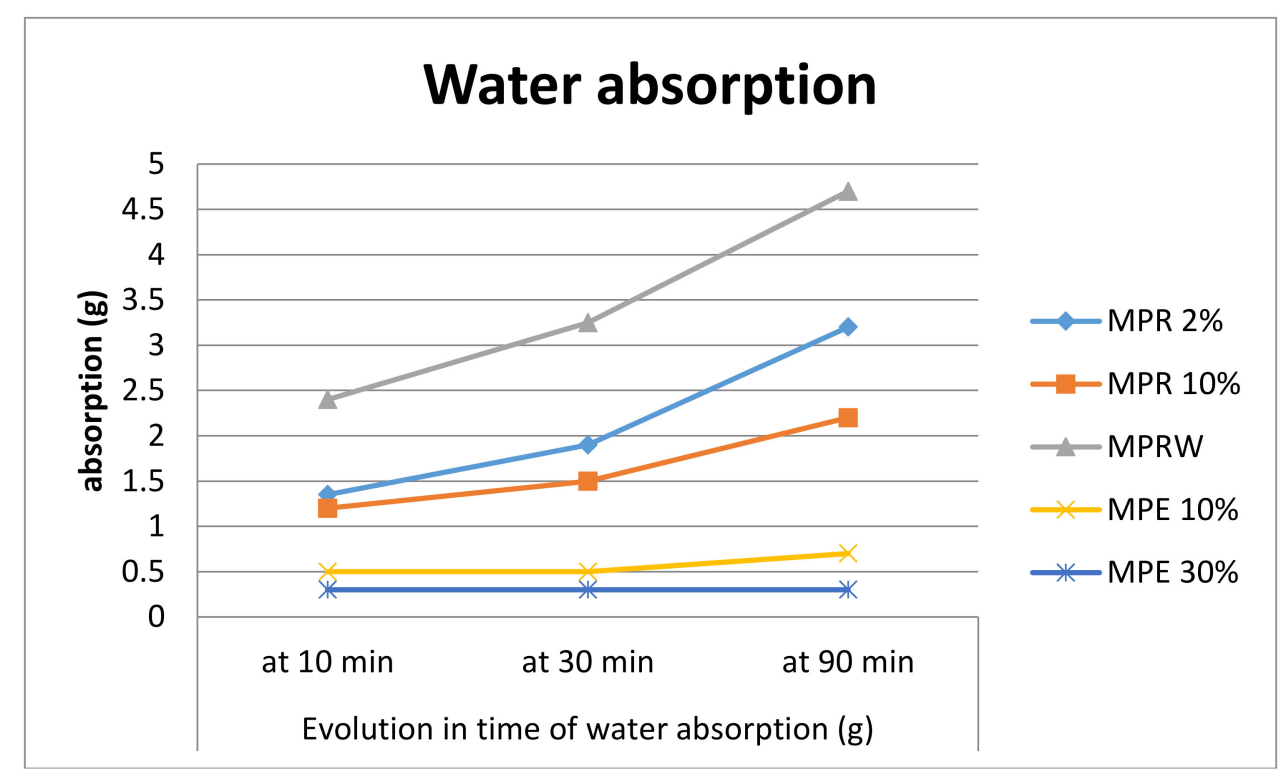

Figure 5. Graphical representation of water absorption at 10, 30, and $90 \mathrm{~min}$ for the mortars MPR 2\%, MPR 10\%, MPRW, MPE 10\%, MPE 30\%.

\subsection{Determination of the Softening Coefficient}

For the study of the softening coefficient, six specimens of size $160 \times 40 \times 40 \mathrm{~mm}$ were produced for each formula. The specimens were used for the flexural tensile tests, the resulting half prisms being tested for the softening coefficient.

Table 2 summarizes the average values of the softening coefficient $(\mathrm{K})$ for the mortars under research for the purpose of the present article.

Table 2. Average values of the softening coefficient.

\begin{tabular}{cc}
\hline Formula & Softening Coefficient $(\boldsymbol{K})$ \\
\hline CS IV & 0.98 \\
MPC 2\% & 1.00 \\
MPC 10\% & 0.78 \\
MPR 2\% & 0.98 \\
MPR 10\% & 0.77 \\
MPRW & 0.98 \\
MPE 10\% & 0.95 \\
MPE 30\% & 0.87 \\
\hline
\end{tabular}

Figure 6 includes all the mortars subjected to tests for the softening coefficient in our experiment. One can notice that the higher the polymer content in the mortar, the more diminished the softening 
coefficient. The best softening coefficient is in MPC $2 \%$, followed by CS IV, MPR 2\%, and MPRW. Adding polymers (casein, rice, egg white) in small amounts, improves the softening coefficient of the mortars.

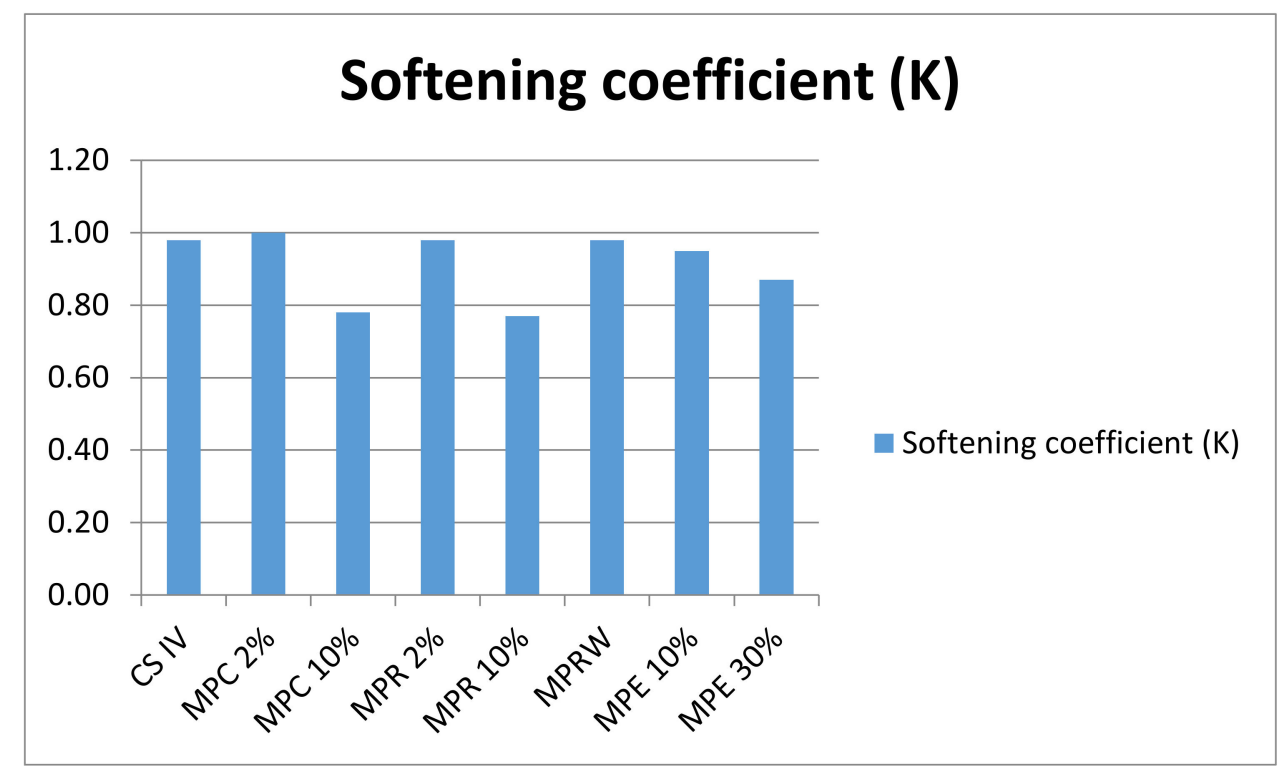

Figure 6. Average softening coefficient values at 28 days for the mortars investigated in the research program.

\section{Conclusions}

This research established that natural polymers used as additives in plaster mortars contribute to diminishing water absorption and even to impermeability.

The influence of the polymer (casein) is made evident as water absorption decreases as compared to the normal plaster mortar. With an increase in the polymer amount, water absorption diminishes.

The formula with a $10 \%$ casein addition to the plaster mortar is one of the best performing formulae for water absorption, ranked second with the $10 \%$ egg white addition mortar.

Rice does not have such a beneficial influence as casein. The values of water absorption in the rice-based mortars increase in time, while those with casein and egg white standstill or increase very little.

Following the experimental program, it was found that adding egg to the mortar formula leads to a very low water absorption level. The formula with $30 \%$ egg absorbs the smallest amount of water in the first $10 \mathrm{~min}$ and then it absorbs water in such small quantity that it can be said to become almost impermeable.

As for the softening coefficient, it shows that the higher the polymer percentage in the mortar, the stronger the softening effect is. The best softening coefficient concerns the mortar formula with $2 \%$ casein.

The objective of our paper was reached. Of the three polymers tested in the experimental program (casein, rice, egg), the best behavior belongs to the mortar with egg white additions in so far as water behavior is concerned: regarding the water absorption and the softening coefficient.

\section{References and Notes}

1. Pintea, A.O.; Manea, D.L. Influence of natural polymers upon cement-based plastering mortars. In Proceedings of the C65 International Conference, Cluj-Napoca, Romania, 12-17 November 2018; pp. 69-70.

2. Popa, D.V. Contribuții la Teoria și Practica Asanării Fundațiilor și Pereților Pentru Construcții Istorice și Social Culturale; Casa Carții de Știință: Cluj-Napoca, Romania, 2007. 
3. Popa, A. Consolidarea Fundatiilor; UTPress: Cluj-Napoca, Romania, 2009.

4. Farcas, V. Reabilitarea Fundatiilor Constructiilor Social Culturale și Industriale; UTPress: Cluj-Napoca, Romania, 2014.

5. Istudor, I. Detalii Tehnice ale Picturii de la Voroneț: Art Conservation Support. Available online: http: //acs.org.ro/ro/conservare/255-detalii-tehnice-ale-picturii-de-la-voronet (accessed on 3 February 2021).

6. Anonymous. Secretele “Albastrului de Voroneţ” şi “Albului de Humor”. Available online: http://www.gandul. info/reportaj/secretele-albastrului-de-voronet-si-albului-de-humor-3197351 (accessed on 3 February 2021).

7. Anonymous. “Tainele Mănăstirii Voroneţ. Zece Lucruri Mai Puţin Ştiute Despre Capela Sixtină a Estului şi Despre Cum a Apărut Superba Culoare Albastru de Voroneţ". Available online: https://identitatea. ro/tainele-manastirii-voronet-zece-lucruri-mai-putin-stiute-despre-capela-sixtina-a-estului/ (accessed on 3 February 2021).

8. Anonymous. Manastirea Humorului. România Montană. Available online: http://romania-montana.ro/en/ proprietate/judet/suceava/manastirea-humorului/ (accessed on 3 February 2021).

9. Acharya, A.; Archroy, S.; Gokhale, V.A. Role of Additives in Mortars: Historic Precedents. Int. J. Eng. Res. Appl. 2017, 7,7-12. [CrossRef]

10. Sekar, S.K.; Thirumalini, S. Review on Herbs used as Admixture in Lime Mortar used in Ancient Structures. Int. J. Appl. Eng. Res. 2013, 3, 295-298.

11. Yang, F.; Zhang, B.; Pan, C.; Zeng, Y. Traditional mortar represented by sticky rice mortar-One of the great inventions in ancient China. Sci. China E Technol. Sci. 2008, 52, 1641-1647. [CrossRef]

12. Vintilă-Bolchiș, O. Marele Zid Chinezesc a Rezistat Sutelor de ani, Datorită ... Orezului. Available online: http://jurnalul.ro/afla-ce-e-nou/marele-zid-chinezesc-a-rezistat-sutelor-de-ani-datorita-orezului545810.html (accessed on 3 February 2021).

13. Pintea, A.O.; Manea, D.L. New types of mortars obtained by aditiving traditional mortars with natural polymers to increase physico-mechanical performances. In Proceedings of the International Conference INTER-ENG 2018, Targu Mures, Romania, 4-5 October 2018.

14. Pintea, A.O.; Manea, D.L. Influence of natural organic polymers upon plaster mortar workability. In Proceedings of the International Conference INTER-ENG 2019, Targu Mures, Romania, 3-4 October 2019.

15. Partea 18: Determinarea coeficientului de absorbţie a apei datorată acţiunii capilare a mortarelor întărite. In Metode de Incercare a Mortarelor Pentru Zidărie; SR EN 1015-18:2004; ASRO: Bucharest, Romania, 2004.

16. Partea 11: Determinarea rezistenţei la încovoiere si compresiune a mortarului întărit. In Metode de Incercare a Mortarelor Pentru Zidărie; SR EN 1015-11:2002/A1:2007; ASRO: Bucharest, Romania, 2007.

Publisher's Note: MDPI stays neutral with regard to jurisdictional claims in published maps and institutional affiliations.

(C) 2021 by the authors. Licensee MDPI, Basel, Switzerland. This article is an open access article distributed under the terms and conditions of the Creative Commons Attribution (CC BY) license (http://creativecommons.org/licenses/by/4.0/). 